\section{Quaternary folding in the south piedmont of central segment of Tianshan Mountains}

\author{
LU Huafu ${ }^{1}$, Wang Shengli ${ }^{1}$, JIA Dong ${ }^{1}$, J. Suppe ${ }^{2}$, \\ A. Hubert-Ferrari ${ }^{2}$, YIN Donghao ${ }^{1}$, YAN Fuli ${ }^{1}$ \\ \& CHEN Jian ${ }^{1}$ \\ 1. Department of Earthsciences, Nanjing University, Nanjing 210093, \\ China; \\ 2. Department of Geosciences, Princeton University, NJ08544, USA \\ Correspondence should be addressed to Lu Huafu (e-mail: hflu@, \\ nju.edu.cn)
}

\begin{abstract}
The Tianshan Mountains are an important active structural belt in the interior of Eurasia. By integrated methods of surface geology survey and interpretation of seismic profiles, we distinguish fold scarps located at the south limb of the Kuqatawu anticline and the north limb of the Dongqiulitag anticline in the Kuqa rejuvenation foreland thrust belt, south piedmont of central segment of the Tianshan Mountains. Fold scarp is a newly found structural phenomenon. Because of the bend of thrust plane and the movement of hanging wall above the thrust plane, the original horizontal deposits of hanging wall and their surface become a monocline structure, resulting from the separating and migration of the active and fixed axial surfaces. Measuring the geometry of fold scarp and using the data of age of the deformed deposits, the crustal shortening rate resulting from the deeply seated subsurface thrust is calculated. The crustal shortening rate reflected by the fold scarp located at the north limb of the Dngqiulitag anticline is $(1 \pm 0.1) \mathrm{mm} / \mathrm{a}$. The fold scarps of the Dongqiulitag anticline and the $\mathrm{Ku}$ qatawu anticline identify that the deformation process of the crustal compressive structures in the Kuqa area extends into the Late Quaternary.
\end{abstract}

Keywords: Tianshan Mountains, Kuqa, fold scarp, crustal shortening rate, fault-related fold.

The thrusting and folding are widely spreading in the area between the Tianshan Mountains and the Tarim Basin, and they especially intensively develop in the Kuqa ${ }^{[1,2]}$ and the Kalping rejuvenation thrust belts ${ }^{[3]}$. The Kuqa rejuvenation foreland thrust belt, from Wensu County at the west to the town of Kuerchu, $470 \mathrm{~km}$ in length, is a rejuvenation foreland deformation belt, occurring to the south of the Tianshan Paleozoic collision orogeny ${ }^{[1,4]}$. With continuous enforcement of gas and petroleum exploration in the Kuqa area, large numbers of seismic profiles have been made, which allows us to more understand the features of the Kuqa rejuvenation thrust belt ${ }^{[1,2,5-12]}$.
By means of interpreting many seismic profiles, it is revealed that the structures in the Kuqa rejuvenation foreland deformation belt are fault-related folds, including fault-bend fold, fault-propagation fold, duplex, detachment fold, etc. ${ }^{[9]}$. The rejuvenation foreland deformation belt comprises a thrust wedge as a whole, while the sole thrust detachment expresses shallowing southward and the main detachment disappeared beyond the Yaken anticline occurring in the frontier of the thrust belt. The growth strata deposited during the processes of folding record the sequences of structural deformation, the initial ages of which become younger and younger from north to south, i.e. $24 \mathrm{Ma}$ (early Miocene) in Sidk anticline zone, 19.6 $\mathrm{Ma}$ (middle Miocene) in the North anticline zone, 3.6 Ma (middle Pliocene) in the Baicheng basin, 3.1 Ma (middle Pliocene) and 1.8 Ma (early Pleistocene) in the South anticline zone respectively (fig. 1) ${ }^{[7,9]}$. Quaternary faulting in this area has been researched ${ }^{[14,15]}$. The fold scarp is a new concept, which was suggested by J. Suppe and has been studied primarily in the Kuqa area, but not published formally ${ }^{1)}$. Using the integrated methods of surface geology survey and interpretation of seismic profiles, we validated that the fold scarps occurred in the Quaternary deposits in the Kuqa rejuvenation thrust belt. The fold scarps implicate that the movement of the subsurface thrust under them during Quaternary results in special fault-bend folding. The Quaternary fold scarps can be used to calculate the Quaternary crustal shortening rate and at the same time identify that the deformation time of fault-related folding of Kuqa rejuvenation thrust belt extended into late Quaternary.

\section{Geological setting}

According to the deformation features, the natural compositions of structures, and the distribution of positive and negative structures in the rear part of thrust-fold belt of the Kuqa rejuvenation foreland basin ${ }^{[1]}$, the Kuqa rejuvenation foreland thrust belt is divided into five zones: (1) Boundary Thrust/Structural wedge, (2) Sdik Anticline zone, (3) North Anticline zone, (4) Baicheng Basin, and (5) South Anticline zone ${ }^{[7]}$ (fig. 1). According to the proofs of the growth strata, the deformation of the zones occurred from north to south gradually in the span of geological time. The Quaternary fold scarps appear at the north limb of the Dongqiulitag anticline and the south limb of the Kuqatawu anticline in the South Anticline zone.

2 The fold scarp at the south limb of the Kuqatawu anticline

The fold scarp, a new structural concept, is a monoclinal fold slope which is formed from the initial horizontal or subhorizontal strata or unconsolidated deposits, experienced fault-bend folding which resulted from the

1) Hubert-Ferrari, A. et al., Actively growing fault-bend fold and detachment fold in the Kuche area (Southern Tianshan, China) in The Princeton 3D Structure Project Industrial Affiliates Program, Third Affiliates Meeting (ed. J. Suppe), Princeton University, 2000. 


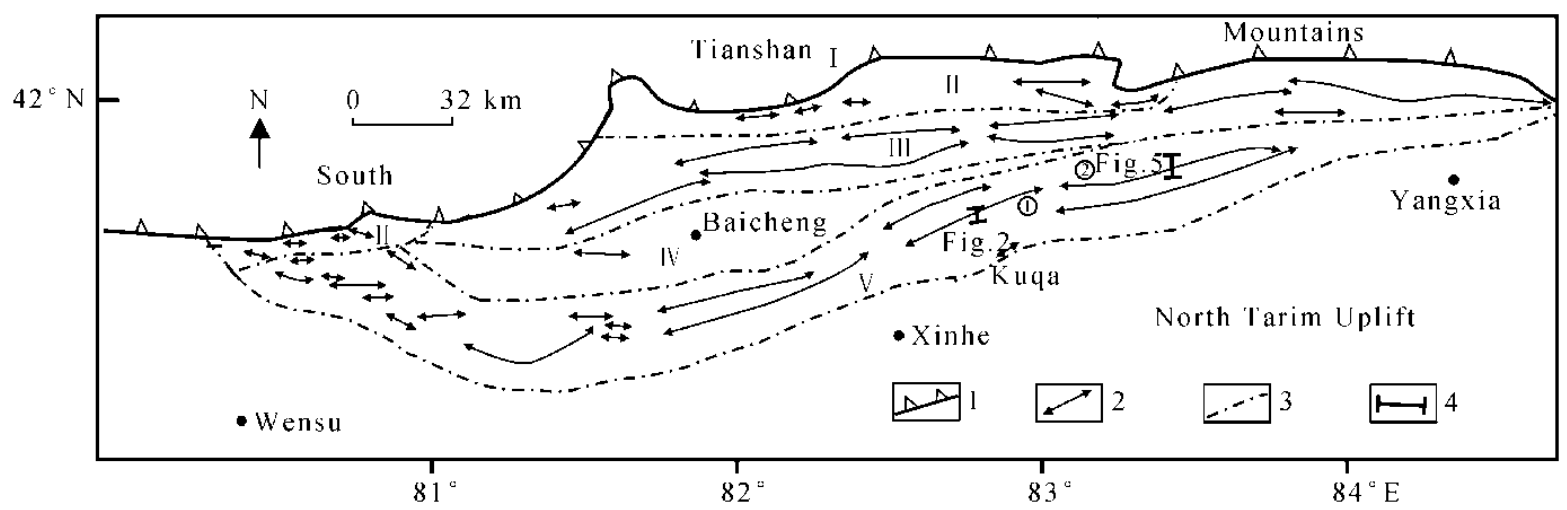

Fig. 1. Tectonic map of the Kuqa rejuvenation foreland thrust belt (after Lu et al., 1999 ${ }^{[7]}$ ). 1, Thrust; 2, anticline axis; 3, boundary of structural zone; 4, location of seismic profile; I , boundary Thrust/Structural zone; II, Sdik Anticline zone; III, North Anticline zone; IV, Baicheng Basin; V, South Anticline zone; (1) Kuqatawu anticline; (2) Dongqiulitag anticline.

subsurface thrusting of deeply seated thrust or blind thrust, with separating and migration of the fixed and the active axial surfaces, and on both sides of the monocline, the strata or deposits are conserved in horizontal or subhorizontal attitude.

The deep part of the Kuqatawu anticline is a fault-bend fold anticline with a passive roof back thrust $\left(F_{2}\right.$ in Plate I (upper)) on its south limb. Because of the strong resistance on the south side, so that it is a detachment anticline in its shallow part. Therefore as a whole the Kuqatawu anticline is a superimposed detachment/faultbend anticline ${ }^{[9]}$ (Plate I (upper)). The Fold scarp caused by activity of the back thrust is observed (Plate I ) at the south limb of the Kuqatawu anticline. On the north side of the fold scarp, unconsolidated Quaternary deposits overlay the layers of the Pliocene Kuqa Formation in the attitude of $70^{\circ} / \mathrm{S} \angle 40^{\circ}$ in unconformity. On the south side of the fold scarp the Quaternary is the deposits of terrace II of the river. The attitude of Kuqa Formation close to the core of the Kuqatawu anticline is much steep, even vertical. Southward from there, the geomorphology changes, and the unconsolidated Quaternary deposits of terrace II are folded and form a slope of $10^{\circ}$ south dipping surface, which is the 'fold scarp'. On the fold scarp, the unconsolidated Quaternary terrace deposits comprise the gray low roundness gravels, continuously covering the Pliocene Kuqa Formation unconformably. On the north and the south of the fold scarp, the sediments are conserved in the horizontal state. The north horizontal sediments are 24 $\mathrm{m}$ higher than the river bed, and the south ones are lower, $7 \mathrm{~m}$ higher than the river bed. Beneath the fold scarp, the dips of the layer planes of the upper Kuqa Formation and the Xiyu Formation conglomerates covered by terrace II gradually become lower and lower southward, and to the bottom of the slop of the fold scarp the layers become horizontal. Then in consequence to the south the Xiyu Formation is horizontal and parallel with the deposits of terrace II. The Quaternary sediments of terrace II on the fold scarp are continuous with those of both sides of the fold scarp, and are not cut by any fault. Therefore, the differences of attitude and the elevation of the sediments of terrace II are induced by the buried thrusting. The fold scarp is distributed continuously along the south limb of the Kuqatawu anticline, extending east-west, more than ten kilometers long. The mechanics and evolution of the fold scarp can be interpreted by the fault-related theory ${ }^{[13,16,17]}$ and the related erosion, depositing and growth strata $^{[13]}$ presented by J. Suppe. Suppe et al. (1997) introduced the conception of the curved hinge between flat and ramp, which is the hinge zone. The growth strata in the hinge zone exhibit dual features of limb rotation and kink band migration. The fold scarp at the south limb of the Kuqatawu anticline has these features obviously. Suppe et al. explained the evolution of the fold scarp with fig. $2^{[18]}$. Fig. 2(a) shows the early deformation of the rear limb of the fault-bend fold anticline that resulted from the back thrust caused by blind stepped southward thrusting. Fig. 2(b) shows that the fault-bend fold anticline was eroded. Fig. 2(c) shows that the horizontal sedimentary strata were deposited on the erosion surface. Fig. 2(d) shows that the depositing and the deformation occurred contemporaneously, and the present fold scarp was formed. Therefore the fold scarp at the south limb of the Kuqatawu anticline is the monocline resulting from the fault-bend folding controlled by the back thrust that moved northward. The time span of the growth strata from its beginning to the present is the active time of the thrust which resulted in the fold scarp. 

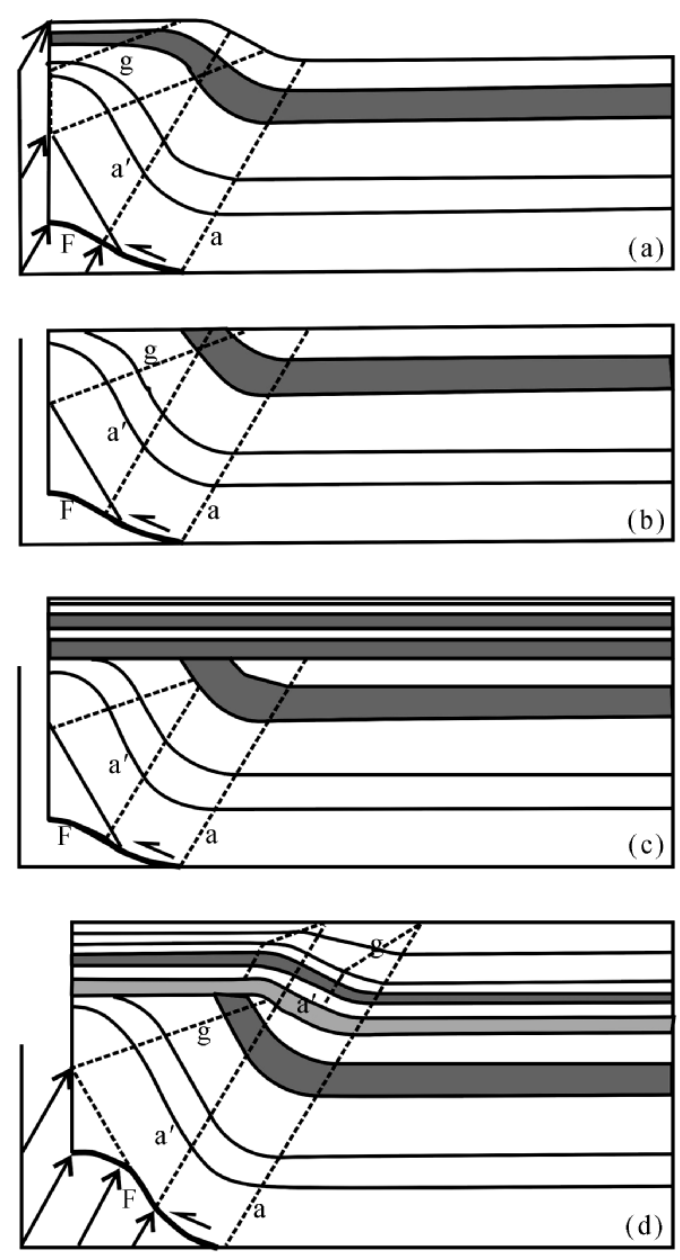

Fig. 2. Evolution model of the fold scarp (after Suppe et al., 1997, modified). a, Active axial surface; $a^{\prime}$, parallel surface of active axial surface; g, growth axial surface; $F$, thrust fault.

\section{The fold scarp at the south limb of the Dongqiultag anticline}

The Dongqiulitag anticline is located at the frontier belt of the Kuqa rejuvenation foreland thrust belt. On the surface the Dongqiulitag anticline is a fault-propagation fold anticline, but there is a fault-bend fold anticline in the deep. The Dongqiulitag anticline is as a whole named the superimposed fault-propagation/bend fold anticline by $\mathrm{Lu}$ et al. ${ }^{[9]}$ (Plate I (lower)). The fold scarp at the north limb of the Dongqiulitag anticline is located about $1 \mathrm{~km}$ to the north of the core of the anticline. The sediments of terrace II of the Bostantuoklak River is deformed into two different elevation flats. At the north flat the sediments are 9 $\mathrm{m}$ higher than the river bed, and at the south flat $18.84 \mathrm{~m}$ higher than the river bed. The fold scarp has expressed the different features from those at the south limb of the Kuqatawu anticline. The shapes of the fold scarp on both banks of the Bostantuolak River are shown in Plate III.
Our observation of the surface geology and interpretation of the seismic profile validate that the above-mentioned different elevations of the sediments of terrace II are caused by fold scarp resulting from fault-bend folding, but are not caused by high angle fault. In the left bank (east bank), although the Quaternary deposits in the hinge zone area of the fold scarp above the bedrocks of the hinge zone have been eroded (the middle and lower of Plate III), by the right bank (west bank) the Quaternary terrace II deposits between both of the two different height flats are well conserved, which are continuous and not cut by any faults (Plate II (upper)). The seismic profile reveals that many reflectors in the Pliocene Kuqa Formation of the north limb of the Dongqiulitag anticline under the fault scarp are continuous and not cut by any faults (Plate I (lower)), which proves that the deformation of terrace II with the two different height flats is the fold scarp, and is not caused by the high angled fault, but by the low angle thrust, the Bositantuoklak fault located at the bottom of Paleogene, which outcrops at the south limb of the Dongqiulitag anticline (Plate I (lower)). The hinge zone between the two regions of homogeneous dips is well conserved on surface and the width of the curved hinge zone is no more than $1 \mathrm{~m}$ (Plate III). Beneath both sides of the fold scarp, the relationship between the Quaternary terrace II and the Kuqa Formation is in angular unconformity (Plate III). The attitude of Pliocene Kuqa Formation on the north side of the fold scarp is $90^{\circ} / \mathrm{N} \angle 25^{\circ}$, and that on the south side of it is $94^{\circ} / \mathrm{N} \angle 60^{\circ}$. At the boundary between the fold scarp and the north flat, the attitude of Pliocene Kuqa Formation changes abruptly. The interpretation of the seismic profile approves that the fault scarp at the north limb of the Dongqiulitag anticline is resulted from the movement of the Bositantuoklak fault in the deep (Plate I (lower)). It is notable that the boundary between the two regions of homogeneous dip is very sharp, identifying a narrow hinge zone in fact a angular hinge surface or axial surface. From this phenomenon we speculate that the different segments of the buried thrust change abruptly, suggesting that the bend of it is angular. The evolution model of the fold scarp is shown in fig. 3. Fig. 3(a) shows that before Quaternary deposited the movement of the blind stepped thrust (not shown in the figure) led the hanging wall strata to become into two regions of homogeneous dips by means of kink band migration, and the boundary surface between the two regions is the active axial surface. And then bedrocks were eroded, and the Quaternary terrace II deposited. In fig. 3(b), as the buried thrust reactivated, the previous fold continued developing by means of kink band migration, and the previous active axial surface bended and became active axial surface $a$ and fixed axial surfaced $b$ in the overlaying young 


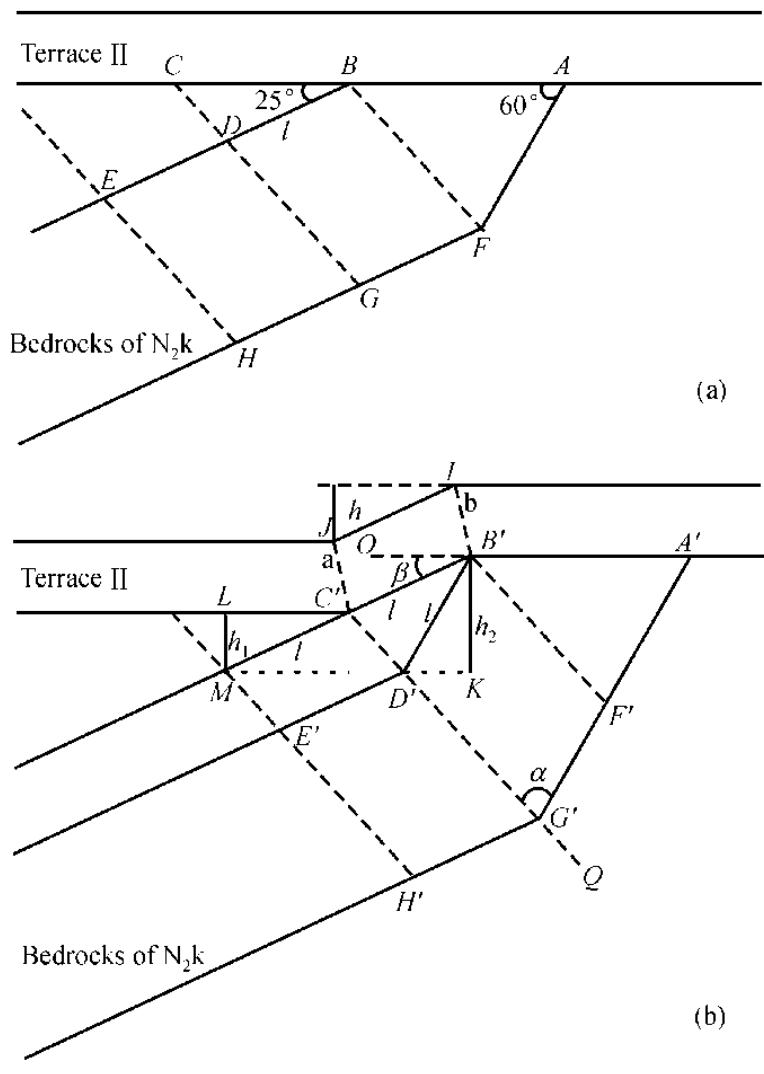

Fig. 3. Evolution model of the fold scarp at the north limb of the Dongqiulitag anticline. (a) Before the deformation of terrace II; (b) the deformation of terrace II; a, active axial surface; $b$, fixed axial surface.

terrace II strata. In the Quaternary terrace II deposits the fixed axial surface migrated southward with the deformation of terrace II and induced the present fold scarp which is different from that at the south limb of the Kuqatawu anticline. On the east bank of the river, the site of the fold scarp there happens a present channel, where the unconsolidated terrace II deposits were eroded. By means of geometric methods, fortunately the height difference between the two flats of terrace II surface can be measured, which is $9.84 \mathrm{~m}$. Geometric and kinematic features mentioned above allow us to calculate the slip of the buried thrust. The slip of the buried thrust (the Bostantuokla fault in Plate I (lower)) is $L=9.84 /\left(\sin 60^{\circ}-\sin 25^{\circ}\right)$ $=22.19 \mathrm{~m}$.

The proof is as follows:

( i ) The geometry of the deformation caused by the fault slip on a bended thrust plane which resulted in the syncline and the fold scarp is shown in fig. 3 .

In fig. 3(a), the bedrocks of the Kuqa Formation strata are already deformed into a syncline whose limbs are controlled by and parallel with the fault plane of the buried thrust which is bended across the axial surface BF and is not shown in fig. 3. The attitudes of the rear and the front limbs of the syncline are $25^{\circ}$ and $60^{\circ}$ dipping to north respectively, which means that the dipping angles of the segments of the bended buried thrust are $25^{\circ}$ and $60^{\circ}$ respectively. Line $\mathrm{BE}$ and $\mathrm{AFH}$ represent the unbended and bended layer planes of the Kuqa Formation strata respectively. The bedrock syncline is eroded and then receives the horizontal terrace II deposits on the erosion surface.

In fig. 3(b), the thrust reacted after the deposition of terrace II and resulted in the deformation of the latter. The fault slip is $l$ equal to the line $B^{\prime} D^{\prime}$. The material line $C D G$ in fig. 3(a) is moved to the position of syncline axial surface as the material line $C^{\prime} D^{\prime} G^{\prime}$ in fig. 3(b). The material line BF at the axial surface in fig. 3(a) is moved at the position of $B^{\prime} F^{\prime}$ in fig. 3(b), and bended layer plane $A F G$ in fig. 3(a) now becomes a straight line $A^{\prime} F^{\prime} G^{\prime}$ in fig. 3(b). The terrace deposits are bended and the fold scarp is formed which is a monocline represented by line $\mathrm{IJ}$ as their surface and the line $B^{\prime} C^{\prime}$ as their bottom in fig. 3 (b). The active axial surface $J C^{\prime}(a)$ and the fixed surface $I B^{\prime}$ (b) are formed in the terrace deposits (fig. 3(b)).

(ii) The presumptions are as follows: (1) Dipping angle of rear limb of syncline: $25^{\circ}$; (2) dipping angle of the front limb of syncline: $60^{\circ}$; (3) fault slip: $l$ equal to the migration distance between the active axial surface and the fixed axial surface in the terrace deposits, i.e. $l=B^{\prime} C^{\prime}$, and to the line $B^{\prime} D^{\prime}$ in the bedrock of the Kuqa Formation strata respectively; (4) $B F$ and $C^{\prime} D^{\prime} G^{\prime}$ : the active axial surface in the bedrocks before and after the fault movement after the terrace deposits; (5) $J C^{\prime}$ : the active axial surface in the terraces deposits; (6) $I B^{\prime}$ : the fixed axial surface in the terraces deposits;

(iii) Identification of the dipping angle of the fold scarp (see fig. 3(b))

The line $C^{\prime} G^{\prime}$, the active axial surface bisects the interlimb angle of the syncline $H^{\prime} G^{\prime} A^{\prime}$. Therefore, we have the half value $(\alpha)$ of the syncline interlimb angle:

$\alpha=\angle A^{\prime} G^{\prime} D^{\prime}=\left(180^{\circ}-60^{\circ}+25^{\circ}\right) / 2=72.5^{\circ}$.

Because of $B^{\prime} D^{\prime} / / A G^{\prime}$, then $\angle B^{\prime} D^{\prime} C^{\prime}=72.5^{\circ}$.

$B^{\prime} D^{\prime}$ is the fault slip in the bedrocks and $B^{\prime} C^{\prime}$ is the fault slip in the terrace deposits. They are equal to each other, i.e. $B^{\prime} D^{\prime}=B^{\prime} C^{\prime}=l$. In the $\Delta B^{\prime} C^{\prime} D^{\prime}$, because of $B^{\prime} D^{\prime}=B^{\prime} C^{\prime}$ and $\angle B^{\prime} D^{\prime} C^{\prime}=72.5^{\circ}$, so we have $\angle B^{\prime} C^{\prime} D^{\prime}=72.5^{\circ}, \angle C^{\prime} B^{\prime} D^{\prime}=35^{\circ}$.

Extend the horizontal line $A^{\prime} B^{\prime}$ to the point $O$. Let line $B^{\prime} K$ to be vertical, so that $\angle O^{\prime} B^{\prime} K$ is $90^{\circ}$. Then we got the dipping angle $\beta, \angle O^{\prime} B^{\prime} C^{\prime}=90^{\circ}-30^{\circ}-35^{\circ}=$ $25^{\circ}$.

So the conclusion is that the dipping angle of the fold scarp is equal to the one of the rear limb of the bedrocks syncline.

(iv) Calculation of the fault slip or the shortening (see fig. 3(b))

The magnitudes of uplift of the rear and the front limbs of the syncline are $h_{1}$ and $h_{2}$ respectively, while the fault slip is $l$.

$$
\begin{aligned}
& h_{1}=l \sin 25^{\circ}, \\
& h_{2}=l \sin 60^{\circ} .
\end{aligned}
$$

The difference between the two uplifts of the rear and the front limbs of the bedrocks is $h=h_{2}-h_{1}$.

Therefore, the fault slip is able to be calculated from the dipping angles of the limbs of syncline and the difference of uplift of the syncline limbs which could be measured in the field. 


\section{$l=h /\left(\sin 60^{\circ}-\sin 25^{\circ}\right)$.}

In the area the Quaternary sediments are unconsolidated terrace II gravel of the Bostantuoklak River, rather than the semi-consolidated Xiyu Formation gravel $\left(\mathrm{Q}_{1 \mathrm{x}}\right)$. Bai Meixing ${ }^{[19]}$ reported that the thermoluminescence (TL) age of terrace II of the Yaha River, located only about 4 $\mathrm{km}$ to the west of the Bostantuoklak River, is $(25100 \pm$ 1900) aBP, and summarized the ages of terrace II in the south and north piedmont of Tianshan Mountains as (12.5 $-36.7) \times 10^{3}$ aBP. Because these two rivers are closely adjacent to each other and both cut the Dongqiulitag anticline and other related structures in this area, we deduce that the age of terrace II of the Bostantuoklak River is equal to that of the Yaha River. Terrace I of the Bostantuoklak River is $2 \mathrm{~m}$ higher than the river bed without observed deformation, so we conclude that the buried thrust did not activate or activate weakly after the beginning of terrace I . Therefore the fold scarp is mainly formed before the deposition of terrace I . According to Bai's analysis of the terrace age ${ }^{[19]}$ in Xinjiang, the age of terrace I of the Bostantuoklak River is deduced as 2669 \pm 102 years old. From these data, we calculate that the slip rate of the buried thrust (the Bostantuokla fault in Plate I (lower)), which resulted in the fold scarp, is $(1 \pm$ $0.1) \mathrm{mm} / \mathrm{a}$.

\section{Discussion and conclusion}

The concept of the Tianshan Mountains Paleozoic collision orogeny related with the India-Eurasia continent-continent collision is accepted widely ${ }^{[1-4,21,22]}$. Some results of crustal shortening rate have been obtained. In the light of the growth strara, Lu et al. reported that the relatively quick crustal shortening in the Qiulitag frontier zone of the Kuqa rejuvenation foreland thrust belt is $3-4$ $\mathrm{mm} / \mathrm{a}$ during Pliocene to Quaternary ${ }^{[8,9]}$. Lu et al. estimated the crustal shorting rate in late Quaternary in Jiamu area was $2 \mathrm{~mm} / \mathrm{a}^{[14]}$. Avouac et al. concluded that the crustal shortening rate across the Tianshan Mountains is up to $(6 \pm 3) \mathrm{mm} / \mathrm{a}^{[20]}$. Allen et al. pointed out that the crustal shortening rate in the Kalping area is $1.8 \mathrm{~mm} / \mathrm{a}^{[3]}$. Yin et al. presented that the late Cenozoic crustal shortening rate in the Kuqa area is $1-1.9 \mathrm{~mm} / \mathrm{a}^{[21]}$. Wang et al.'s GPS measurement indicates that the crustal shortening rate from Alaer of the Tarim Basin to Kuitun of the Jungar Basin is about $8 \mathrm{~mm} / \mathrm{a}^{[22]}$. All studies mentioned above indicate that the late Cenozoic crustal shortening rate in the Kuqa area of the south piedmont of the Tianshan Mountains is about $1-4 \mathrm{~mm} / \mathrm{a}$. The fold scarp of terrace II resulting from the deformation at the north limb of the Dongqiulitag anticline directly proves the movement of the deep buried thrust, the Bostantuoklak thrust during late Quaternary, the slip rate of which is $(1 \pm 0.1) \mathrm{mm} / \mathrm{a}$. This is the only contribution of the Bositantuoklak fault to the crustal shortening of the Tianshan Mountains, which is less than the total crustal shortening rate $1-4 \mathrm{~mm} / \mathrm{a}$ of the southern Tianshan Mountains. That is reasonable, because there are other Quaternary compressive structures in the south of the Kuqatawu anticline, the Yaken anticline to the south of the Dongqiulitag anticline and the north margin thrust of the Kuqa thrust belt.
Acknowledgements We thank Tarim Petroleum Co. (Tarim Petroleum Exploration and Development Bureau, CNPC) for its permission to use the seismic profiles in the note. This work was supported by the National Natural Science Foundation of China (Grant No. 49832040).

\section{References}

1. Lu, H., Howell, D. J., Jia, D. et al., Rejuvenation of the Kuqa foreland basin, northern flank of the Tarim basin, Northwest China., International Geology Review, 1994, 36: 1151.

2. Liu Hefu, Liang Huishe, Cai Liguo et al., Evolution and structural style of Tianshan and adjacent basins, Northwest China, Earth Sciences-Journral of University of Geosciences (in Chinese with English abstract), 1994, 19(6): 727.

3. Allen, M. B., Stephen, J. V., Paul, J. W., Late Cenozoic tectonics the Kepingtage thrust zone: Interaction of the Tien Shan and Tarim Basin, northwest China, Tectonics, 1999, 18(4): 639.

4. Windley, A. F., Allen, M. B., Zhang, C., Paleozoic accretion and Cenozoic redeformation of the Chinese Tien Shan range, central Asia, Geology, 1990, 18: 128.

5. Tang Liangjie, A discussion on the multi-level detachment structures and petroleum potential of the Tarim basin, Acta Geologica Sinica (in Chinese with English abstract), 1992, 66(2): 97.

6. Jia Dong, Lu Huafu, Cai Dongshegn, Structural analysis of Kuqa foreland fold-thrust belt along the northern margin of Tarim Basin, Geotectonica et Metallogenia (in Chinese with English abstract), 1997, 21(1): 1.

7. Lu Huafu, Jia Dong, Chen Chuming et al., Natural and Timing of the Kuqa Cenozoic structures. Earth Sciences Frontier (Chinese University of Geosciences, Beijing) (in Chinese with English abstract), 1999, 6(4): 215 .

8. Lu Huafu, Chen Chuming, Liu Zhihong, The structural features and origin of the Kuqa rejuvenation foreland thrust belt, Acta Petrolei Sinica (in Chinese with English abstract), 2000, 83(30): 18

9. Lu, Huafu, Jia, Chengzao, Jai, Dong et al., Features of thrust wedge of deformation belt in Kuqa rejuvenation foreland basin, Geological Journal of China Universities (in Chinese with English abstract), 2001, 7(3): 257.

10. Chen Chuming, Lu Huafu, Jiadong et al., Structures and petroleum accumulation in the Qiulitage frontier of Kuqa rejuvenated foreland fold-thrust belt on the northern margin of Tarim Basin, Geological Review (in Chinese with English abstract), 1999, 45(4): 423.

11. Zhou Xingui, Sun Baoshan, Li Yuehui et al., Mechanism of formation of decollement thrust zone and the prospect of oil-gas in Kuche depression in north Tarim Basin, Journal of Geomechaics (in Chinese with English abstract), 1995(2): 71.

12. Liu Zhihong, Lu Huafu, Li Xijian et al., Tectonic evolution of Kuqa rejuvenation foreland Basin (in Chinese with English abstract), Scientia Geologica Scinica. 2000, 35(4): 482.

13. Suppe, J., George, T. C., Stephen, C. H., Rate of folding and faulting determined from growth strata (ed. McClay, K. R.), Thrust Tectonics., New York, Chapman Hall, 1992: 105.

14. Lu Huafu, Wang Whengli, Hubert-Ferrari, A. et al., The Quaternary fault in Jiamu area, the Xinjiang Uygur Autonomous Region, Chinese Science Bulletin, 2002, 47(6): 494.

15. Bai Meixing, Xiang Zhiyong, Hu Jun, Some characters of Queletage fault zone, Inland Earthquake (in Chinese with English abstract), 2000, 14(3): 193.

16. Suppe, J., Geometry and kinematics of fault-bend folding, American Journal of Science, 1983, 283: 684.

17. Suppe, J., Donald, A., Medwedeff. Geometry and kinematics of fault propagation folding, Eclogae Geol. Helv, 1990, 83(3): 409.

18. Suppe, J., France Sabat, Josep Anton Munoz et al., Bed-by-bed fold growth by kind-bend migration: Sant Lorence de Morunys, eastern Paeness, Journal of Structural Geology, 1997, 19(3-4): 443.

19. Bai Meixing, Date of valley terraces in Xingjiang, Inland Earthquake (in Chinese with English abstract), 1998, 12(1): 3.

20. Avouac, J. P., Tapponnier, P., Bai, M. et al., Active thrusting and folding along the northern Tien Shan and late Cenozoic rotation of the Tarim relative to Dzungaria and Kazakhstan, Journal of Geophysical Research, B, Solid Earth and Planets, 1993, 98(4): 6755.

21. Yin, A., Nie, S., Harrison, T. M. et al., Late Cenozoic tectonic evolution of the southern ChineseTian Shan., Tectonics, 1998, 17(1): 1.

22. Wang Qi, Zhang Peizhen, Niu Zhijun et al., Present-day crustal movement and tectonic deformation in China Continent, Science China, Ser. D, 2002, 45(10): 865

(Received June 4, 2002) 